\title{
Heparin and Aspirin in Pregnant Sudanese women with Recurrent Miscarriage Associa- ted with Antiphospholipid Antibodies
}

Yagoub M. A/Magid', Elsir A. Elussein', Maha M. Omer', Samaan I.Samaan', Fawri A/Rabim², Ishag Adam ${ }^{1,3 *}$

\begin{abstract}
This was a prospective clinical trial conducted at Khartoum Fertility Center, during the period June 2002 to February 2005 to investigate the efficacy of unfractionated heparin and low-dose aspirin as prophylaxis against pregnancy loss in 58 pregnant Sudanese women with recurrent $(\geq 3)$ miscarriages associated with antiphospholipid syndrome (APS).

Three (5.1\%) patients had early miscarriages, three $(5.1 \%)$ patients developed pre-eclamptic toxaemia and forty-seven ( $81 \%$ ) of the 58 patients had cesarean delivery. Forty-seven (81\%) women had live births and 8(13.8\%) had preterm deliveries. Eight $(13.8 \%)$ of the neonates were admitted to the intensive care unit for various reasons. There were $6(10.3 \%)$ perinatal deaths, all of them were due to prematurity. None of the patients developed thromboembolic episode. There was no maternal death.

The rate of live birth in this study was consistent with the previous reports. This was a none controlled study; thus controlled clinical trials using low molecular weight heparin are urgently needed. (Afr J Reprod Health 2007; 11[2]:86-89).
\end{abstract}

\section{RÉSUMÉ}

L'héparine et l'aspirine chez les femmes soudanaises enceintes qui ont fait fréquemment des fausses couches liées aux anticorps antiphospholipides Cette étude a été un essai clinique perspective menée au Centre de fécondité à Khartoum au cours de la période du mois de juin 2002 au février 2005 afin d'enquêter l'efficacité de l'héparine nonfractionnée et de l'aspirine à dose faible comme une prophylaxie contre la perte de grossesse chez 58 femmes soudanaises enceintes qui ont fait fréquemment $(=3)$ des fausses couches liées au syndrome d'antiphospholipide (SAP). Trois $(5,1 \%)$ patientes ont fait des fausses couches précoses, trois $(5,1 \%)$ patientes ont fait de la toxémie éclamptique et quarante-sept ( $81 \%$ ) sur les 58 patientes ont accouché à l'aide de l'opération césarienne. Quarante-sept (81\%) femmes ont eu des naissances vivantes alors que huit 8(13,8\%) ont eu des accouchements pré-termes. Huit $(13,8 \%)$ parmi les nouveaux-nés ont été admis dans l'unité de soins intensifs pour des raisons différentes. Il y a eu $6(10,3 \%)$ décès périnatals, tous à cause de la prématurité. Aucune des patientes n'a fait de l'épisode thromboembolique. Il n'y a pas eu de décès maternel. Le taux de naissance vivante dans cette étude était en accord avec les rapports précédents. Celle-ci a été une étude non contrôlée; ainsi, on a besoin des essais cliniques contrôlés à l'aide de l'heparine à poids moléculaire faible. (Rev Afr Santé Reprod 2007; 11 [2]:86-89).

KEY WORDS: miscarriage, pregnancy, heparin, aspirin, Sudan

${ }^{1}$ Khartoum fertility center,The Academy of Medical Sciences and Technology, Sudan. ${ }^{2}$ Faculty of Medicine, Ribat University, Sudan

${ }^{3}$ Faculty of Medicine, University of Khartoum

Correspondence: Dr. Ishag Adam P. O. Box 102 Department of Obstetrics \& Gynecology, Faculty of Medicine, University of Khartoum Khartoum. Sudan. Phone +249912168988, Fax+249183224799 E.mail:, ishagadamm@yahoo.com 


\section{Background}

Antiphospholipid syndrome (APS) is encountered in most areas of clinical medicine with a wide spectrum of signs and symptoms. The etiology and pathogenesis of antiphospholipid syndrome remain uncertain, so its treatment has remained speculative. Recurrent miscarriage affects $1 \%$ of pregnant women, $15-40 \%$ of these women have APS $^{1}$. Recently APS was found to be the main risk factor for recurrent miscarriage among Sudanese women ${ }^{2}$. The optimal therapeutic management of patients with APS during pregnancy is debatable. Low-dose aspirin (LDA), steroid, heparin and combination of these treatments are the treatment for antiphospholipid syndrome $e^{3-5}$. However, because of the controversies in the outcome of these clinical trials, there is a need for further researches in this field of medicine.

\section{Materials and Methods}

This was a prospective descriptive study that investigated the efficacy of unfractionated heparin (UFH) and LDA as prophylaxis against pregnancy loss in pregnant Sudanese women with recurrent miscarriage associated with APS. The study was conducted at Khartoum Fertility Center, during the period June 2002 to February 2005.

Women with three or more documented consecutive pregnancy losses before 20 gestational weeks and antiphospholipid antibodies (anticardiolipin immunoglobulin G and M antibody and /or lupus anticoagulant) were approached to participate in the study. To minimize inter and intrapersonal error, these tests were conducted by the same immunologist using standard ELISA to detect these antibodies. Women were excluded if they had systemic lupus erythromatosis or history of thrombosis, if they had another cause of the recurrent miscarriage or if they did not have two positive tests for antiphospholipid antibodies. At enrollment, clinical history and physical examination, complete blood count, routine biochemical investigation (including thyroid functions) were performed. Once pregnancy was confirmed (if antiphospholipid was already diagnosed before pregnancy) or on discovery of antiphospholipid antibodies during the index pregnancy, the patients were taught to self-administer UFH subcutaneously (5, $000 \mathrm{IU}$, twice daily) and LDA (100 mg, daily, the only available form in Sudan) and were followed with serial ultrasound and clotting profile (including platelets count) every two weeks until delivery. The treatment was continued at full term (37 weeks) and was discontinued only when the patient initiated spontaneous labour or 12 hours before elective cesarean section delivery. The treatment of UFH and LDA were resumed one day after the delivery as maternal thrombosis prophylaxis. The compliance of UFH was assessed by inspection of the injection site and that of LDA by the frequency of the prescriptions and by asking the patient directly.

The outcome measures were the rates of live births, antenatal complications, delivery and neonatal outcomes.

\section{Ethical clearance}

The study received ethical clearance from the Ethical Committee of the Faculty of Medicine, The Academy of Medical Sciences and Technology, Sudan.

\section{Results}

Sixty- one consecutive patients were enrolled in the study; three patients lost to follow-up and the rest (fifty-eight) completed the study. The basic characteristics of the women are shown in table 1.

Three $(5.1 \%)$ patients had early miscarriages. Three $(5.1 \%)$ patients developed pre-eclamptic toxaemia (diastolic blood pressure $>90 \mathrm{~mm} \mathrm{Hg}$ in two readings 6 hours apart with $2+$ or more of proteinurea). One patient suffered diabetes mellitus during pregnancy. Forty-seven $(81 \%)$ of the 58 patients had cesarean delivery. Forty-seven (81\%) women had live births and $8(13.8 \%)$ had preterm deliveries. The mean (SD) birth weight 
Table 1: The basic characteristics of Sudanese women (58) received heparin and aspirin for recurrent miscarriage associated with antiphospholipid antibodies

\begin{tabular}{|l|l|}
\hline The variable & Mean (SD) or $\mathrm{n}(\%)$ as applicable \\
\hline Age, years & $31.6(6.2)$ \\
\hline Weight, $\mathrm{kg}$ & $72.2(13.7)$ \\
\hline Gestational age at enrollment, weeks & $8.1(1.8)$ \\
\hline
\end{tabular}

was $2.7(0.54) \mathrm{Kg}$. One baby had cleft lip. Eight $(13.8 \%)$ of the neonates were admitted to the intensive care unit for various reasons. There were $6(10.3 \%)$ perinatal deaths all of which were due to prematurity. None of the patients developed thromboembolic episode. There was no maternal death.

\section{Discussion}

This is the first published clinical trial to investigate the efficacy of UFH and LDA in APS among Sudanese women. The study showed that the rates of live births and perinatal deaths were $81 \%$ and $10.3 \%$ respectively, most of the perinatal deaths resulted from prematurity. This goes with previous observations ${ }^{6,7}$ using heparin and LDA in spite of the difference in the types of heparin between the present and the former trial. However, both types of heparin (low molecular weight and unfractionated heparin) were reported to have similar results in terms of maternal and fetal complications $s^{6,8}$. This should be weighted against the patients' compliance and the adverse effects of UFH. Surprisingly, even though LMWH was used without LDA, $92.59 \%$ of the cohort delivered live infants 9 . In contrast to the success rate of $70 \%-75 \%$ when UFH was used with LDA compared with the succesful pregnancy rate of $45 \%$ when LDA was used alone ${ }^{7,10}$. However, it has been reported that, the addition of LMWH to LDA did not significantly improve pregnancy outcome in pateints with $\mathrm{APS}^{11}$. In contrast to previous reports, where treatment with LDA and UFH had signficanlty higher rate of live birth in comparison to LDA alone ${ }^{7}$. Patitison and colleagues reported eightyfive percent of the placebo group and $80 \%$ of the aspirin-treated group for APS delivered live infants without signficant difference in antenatal complications or neonatal morbidity between the groups. It is noteworthy that, in the absence of APS, the live birth rate for a prospectively observed group with idiopathic recurrent miscarriage is $75 \%$, with $20 \%$ and $5 \%$ embryo and fetal loss respecively ${ }^{12}$. Neverthless, any discussion of treatment of recurrent miscarriage associted with APS must take into account the spontaneous cure rate which is $50 \%$ among unselected cases and 10\% of women with APS have live birth without treatment ${ }^{13,14}$.

Extensive obstetrical monitoring was performed in this trial and in all clinical trials conducted to investigate APS and its treatment, this might be one of the reasons behind the high perecentage of live births in all these trials in spite of the use of different regimens.

High caesarean section rate $(81 \%)$ was also observed in this trial, probably because many factors like maternal age and the duration of marriage influenced the decision of the operative deliveries rather than APS or its treatment.

In this study, fetal outcome was favourable in $89.7 \%$ of the treated women. This goes with other observations in cohorts of treating pregnant women with APS ${ }^{15,16}$.

This trial, like all other trials in this field, is small but its results bring into question the need for pharmacologic intervention for women with

\footnotetext{
African Journal of Reproductive Health Vol. 11 No.2 August 2007
} 
APS for whom recurrent fetal loss is the only sequela. Our results highlight the need for a large randomized controlled trial to identify the optimal treatment for this group of women. Further controlled clinical trials using LMWH are urgently needed.

\section{REFERENCES}

1. Pattison NS, Chamley LW, Liggins GC, Butler WS. Antiphospholipid antibodies in pregnancy: prevalence and clinical associations. Br J Obstet Gynaecol 1993; 100: 909-913.

2. Ahmed AA, Ortashi OM, Abdelmagied AH, Ramzi MS. Risk factors for recurrent miscarriage in Sudanese women. Saudi Med J 2004; 25:1295-1297.

3. Pattison NS, Chamley LW, Birdsall M, Zanderigo AM, Liddell HS, McDougall J. Does aspirin have a role in improving pregnancy outcome for women with the antiphospholipid syndrome? A randomized controlled trial. Am J Obstet Gynecol 2000; 183:1008-1012.

4. Hanly JG. Antiphospholipid syndrome: an overview. CMAJ 2003; 24: 168: 1675-1682.

5. Nishiguchi T, Kobayashi T. Antiphospholipid syndrome: characteristics and obstetrical management. Curr Drug Targets. 2005; 6: 593-605.

6. Noble LS, Kutteh WH, Lashey N, Franklin RD, Herrada J. Antiphospholipid antibodies associated with recurrent pregnancy loss: prospective, multicenter, controlled pilot study comparing treatment with low-molecular-weight heparin versus unfractionated heparin. Fertil Steril 2005; 83: 684-690.

7. Rai R, Cohen H, Dave M, Regan L. Randomised controlled trial of aspirin and aspirin plus heparin in pregnant women with recurrent miscarriage associated with phospholipid antibodies (orantiphospholipid antibodies). BMJ 1997; 25: 253-257.

8. Franklin RD, Kutteh WH. Effects of unfrac-tionated and low molecular weight heparin on antiphospholipid antibody binding in vitro. Obstet Gynecol 2003; 101: 455-462.

9. Ruffatti A, Favaro M, Tonello M, De Silvestro G, Pengo V, Fais G, Suma V, Chiarelli S, Todesco S. Efficacy and safety of nadroparin in the treatment of pregnant women with antiphospholipid syndrome: a prospective cohort study. Lupus 2005; 14:120-128.

10. Kutteh WH: Antiphospholipid antibodyassociated recurrent pregnancy loss: treatment with heparin and low-dose aspirin is superior to lowdose aspirin alone. Am J Obstet Gynecol. 1996; 174:1584-1589.

11. Farguharson RG, Quenby S, Greaves M. Antiphospholipid syndrome in pregnancy: A randomized, controlled clinical trial of treatment. Obstet Gynecol 2002; 100: 408-413.

12. Brigham S, Conlon C, Farguharson RG: A longitudinal study of pregnancy outcome following idiopathic recurring miscarriage. Hum Reprod 1999; 14: 2868-2871.

13. Liddell HS, Patisson NS, Zanderigo A. Recurrent miscarriage: outcome after supportive care in early pregnancy. Aust N ZJ obstet Gynacol 1991; 31: 320322.

14. Rai RS, Clifford K., Cohen H. Regan L. High prospective fetal loss rate in untreated pregnancies of women with recurrent miscarriage and antiphospholipid antibodies. Hum Repord 1995; 10: 3301-3304.

15. Ruffatti A, Favaro M, Tonello M, De Silvestro G, Pengo V, Fais G, Suma V, Chiarelli S, Todesco S. Efficacy and safety of nadroparin in the treatment of pregnant women with antiphospholipid syndrome: a prospective cohort study. Lupus 2005, 14:120-128.

16. Stone S, Hunt BJ, Seed PT, Parmar K, Khamashta MA, Poston. Longitudinal evaluation of markers of endothelial cell dysfunction and hemostasis in treated antiphospholipid syndrome and in healthy pregnancy. Am J Obstet Gynecol2003; 188:454-460. 